\title{
GEOINFORMATION ANALYSIS OF FACTORS AFFECTING WIND DAMAGE IN THE ŠUMAVA NATIONAL PARK
}

\author{
MARTIN KLIMÁNEK, TOMÁŠ MIKITA, JAROMÍR KOLEJKA
}

\begin{abstract}
Mendel University of Agriculture and Forestry, Zemédělská 3, 61300 Brno, Czech
Republic.E-mail-klimanek@mendelu.cz,tomas@mikita.cz,kolejka@mendelu.cz
\end{abstract}

Received: $12^{\text {th }}$ March 2008, Accepted: $21^{\text {st }}$ December 2008

\begin{abstract}
This project forms part of the "Remotely Accessed Decision Support System for Transnational Environmental Risk Management" (STRiM) project undertaken within the framework of the European Union's INTERREG IIIB CADSES programme. The test took place in a $70 \mathrm{~km}^{2}$ test area within the western part of the Šumava National Park. It is commonly known that windthrow occurs frequently in the Šumava Mountains, and it tends to occur in particular areas. The intensity of windstorms and the amount of damage caused appear to be relatively constant. In the case of Šumava, such meteorological hazards frequently become biotic hazards as they are often followed by bark beetle infestations. We hypothesise that, in particular areas, the incidence of windthrow, the amount of harm done, and the cost of alleviating that damage are in close relationship with natural factors prevalent in the area and with previous human intervention (forestry) in the landscape. Analysis of such factors, and a comparison with actual data on windthrow, showed that a) the most damaged stands were generally found on gently sloping sites of $8-15$ degrees; b) the leeward side of elevations were more heavily damaged; c) non-natural forest stands were subject to more damage; d) damage increased with increasing stand density; e) middle-aged stands of around 12 years were at greatest risk; and f) the most damaged portions of the test area were located at sites with normally drained and deep soils. Further, landscape relief and active surface character appeared to play an important role in modifying wind speed and direction, thereby increasing the wind's devastating power.
\end{abstract}

Keywords windthrow, STRiM, the Šumava National Park, GIS, spatial analysis, windthrow risk map

\section{INTRODUCTION}

In 2005, the Šumava/Bavarian region was singled out as a test area for the "Remotely Accessed Decision Support System for Transnational Environmental Risk Management" project, also known as STRiM. This project, which forms part of the European Union's INTERREG IIIB CADSES programme, focuses on cross-border analysis, classification, quantification and solving of environmental problems, with its main objective being to establish a remotely and commonly accessed system for decision support of risk management at the transnational level. A pilot study relating to forest wind damage is intended to produce formalised procedures to this end using GIS tools and a geodatabase that covers the forested areas on either side of the Czech and Bavarian state border in the 
Sumava region. The results will facilitate the ongoing development of both areas and promote mutual support in crisis management. The use of common geoinformation technologies (GITs) in the project will contribute to the further development of forestry, particularly as regards their application in predicting imminent risk of windthrow. In this way, GITs may significantly contribute, if not to a reduction in the number of devastating winds, then at least to the minimisation of damage and toward speed of recovery.

\section{History of windthrow in the Šumava Mountains}

This mountainous area has been affected for centuries by repeated windthrow. In the original virgin forest, giants 300-500 years old used to grow for up to 80-120 years of their lives in closely spaced canopy and were heavily shaded. The rootage was strongly developed, which gave the trees a considerable wind resistance that was multiplied by other morphological and biological factors.

No evidence of disastrous wind damage can be found in old archive materials. The first records of such damage appear in the 13th century, following the arrival of the first settlers. These were mainly glassmakers, with lesser numbers of charcoal burners and gold prospectors (Vicena 2003; Brázdil et al. 2004; Brázdil et al. 2007). After the decline in glassmaking in the 17 th century, glassworks began to be built again, with a considerable number being relocated into previously unspoilt forest areas where the glassmakers could find plentiful wood and charcoal needed for the glassmaking process. For this reason, the Šmava forest became a prime target for the glass manufacturers. Due to the benevolence of the land authorities and the tolerance of the lords of the manors, the devastation caused was severe. From the 18th century on, landowners gradually became aware of the real value of their forests, marked by the beginning of the economic exploitation of wood within the forest. This gave birth to a number of colonies of forestry workers and the building of such colonies continued up to the beginning of the 19th century. In addition, the systematic construction of a transport network was begun, particularly in order to salvage windthrown timber.

Regeneration of damaged areas of forest was, at that time, traditionally left to natural reproduction. By 1788, however, efforts were being made to reforest old clearings artificially. A more systematic system of reforestation began following large-scale windthrow and bark beetle (Scolytinae sp.) damage during 1833-1834. Between 1868 and 1878, the Šumava forest was affected by a series of devastating windstorms (Ševětínský 1895). The amount of damage these caused was not only the result of local site conditions and terrain configuration but also of various anthropogenic influences. The greatest damage was reported from areas where, a hundred years before, large areas had been clear-felled and the original mixed forest had been replaced by a monoculture of Norway spruce (Picea abies). Forestry workers were unable to salvage these areas following the large-scale windthrow events, and these areas were then subjected to large-scale attacks by the bark beetle in 1872 , culminating in the years $1874-1875$. In November 1875 , there was a further windstorm, this time followed by a massive fall of snow (Jelínek 1985). Huge numbers of tree seedlings were needed to reforest the area. Most of the land, unfortunately, was covered with spruce monoculture. As this was a local species, however, the autochthonous character of the local forest was preserved (albeit only until around 1880). Other large windthrow events took place in the area in 1918, 1955, 1960 and, especially, in 1984. The windthrow event of October 2002 resulted in around 200,000 m3 of fallen timber in the Šumava National Park. During the night of 18 January 2007, windstorm Kyrill totally or partly damaged vast areas of forest in all zones of the Šumava and Bayerischer Wald national parks, which are situated on either side of the state border between the Czech 
Republic and Germany. The volume of fallen timber following windstorm Kyrill approached $850,000 \mathrm{~m} 3$. With the increasing number of windstorms in both the Czech Republic and around the world, thought to be connected with global climate change (Watson et al. 1995), the damage caused by windstorms is likely to increase in the future.

\section{Geographical features of the test area}

The test area, which covers approximately $70 \mathrm{~km}^{2}$, is situated in the western part of the Šumava National Park in the Prášily and Železná Ruda forest districts (Figure 1). The area is bordered by local roads on the Czech side, the southern boundary forming the state border with the Federal Republic of Germany (Bavaria).

Fig. 1: Locality of the Šumava National Park test area in the Czech Republic.

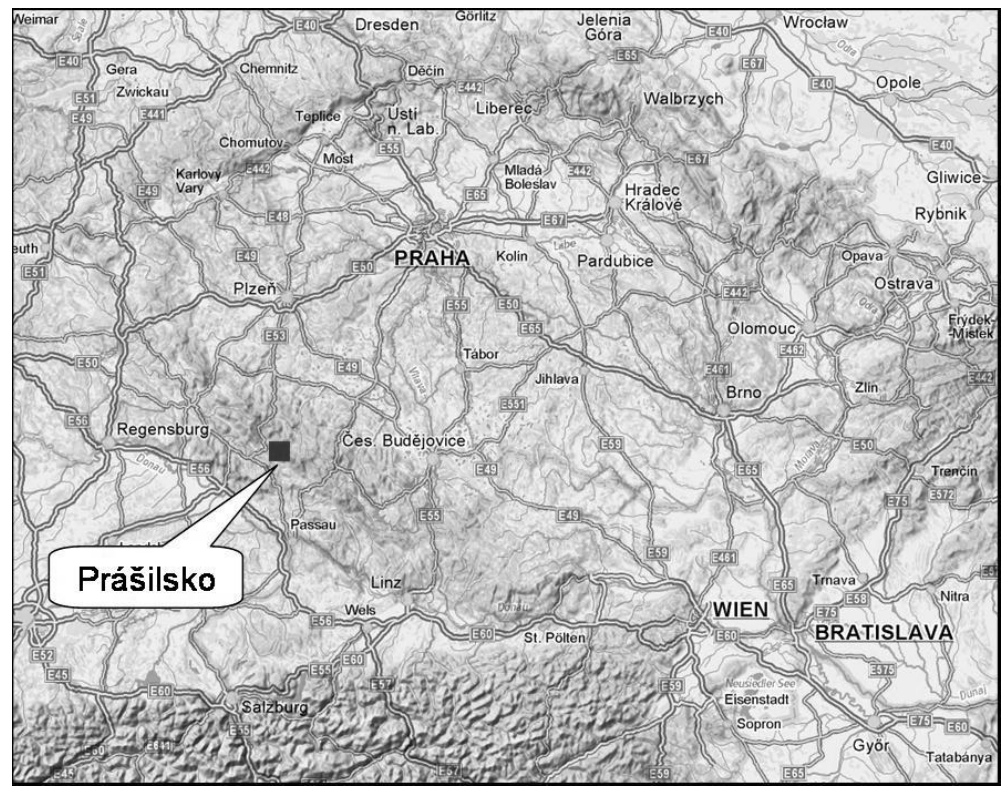

Geologically, the area belongs to the Bohemian part of the Moldanubicum. The western part of the border zone and the central part of the area are composed of migmatites and paragneiss. These parts border a mineral massif comprising schist and gneiss (Vejnar 1991; Pelc 1994). The inland-oriented hillsides of both metamorphosed massifs are rimmed with intrusions of granodiorites and granites of the Šumava pluton. Younger strata are represented by quaternary sediments and products of weathering. Degraded glacial deposits (tills) can be found in the vicinity of the Prášilské and Laka glacial lakes, as well as stony, or even rocky, Pleistocene slope sediments. Solifluction sediments are also frequently found, and these display a great variety of texture. Holocene materials are represented by various sediments, vast peatlands in the valley sites and gravel-sand deposits along watercourses.

The highland or mountainous terrain of the test area is characteristic of the border zone of the Šumava Mountains. Several of the dome-shaped peaks of this ridge attain an altitude of 1,300 m (e.g. Debrník 1,337 m, Ždánidla 1,308 m and Poledník 1,315 m). To the north, the rounded ridge slopes towards low-lying ground along the River Křemelná, which runs, 
together with a system of headwater streams, from west to east. At this point, the altitude drops to $718 \mathrm{~m}$. In many places, the depression has an almost lowland character with numerous peatlands. Relatively deep valleys run out from the depression. Small glacial lakes were formed in the valleys of the Jelení and Prášilský streams during the Pleistocene era. The present hillsides, with their small rock formations (individual rocks, cryoplanation terraces and rock solifluction tongues), were formed through Pleistocene frost weathering and solifluction. The valley floors are usually flat and the streams run amongst narrow, fairly rugged valley floors on sandy (at places gravel) deposits.

From a hydrogeographical point of view, the test area is situated on the main European watershed, approximately $5 \mathrm{~km}$ of which crosses over Czech territory at its northern tip, continuing into German territory around the peak of the Debrník mountain. The headwaters of some right-bank tributaries of the River Křemelná originate in Germany. A small area in the surroundings of the community of Železná Ruda (in the north-western part of the territory) is situated in the Danube basin, the rest being in the Elbe basin. The Laka and Prášilské lakes are of particular interest in this context. Both of these lakes, the areas of which were artificially increased as early as the 19th century by damming their outflows, fill shallow basins on the lower slopes at an altitude of about $1,100 \mathrm{~m}$.

The soil cover is represented by soils bound with various weathering products of siliceous crystalline rocks, ranging from primitive lithosols, through rankers and cambisols, to cryptopodzols and podzols in upland areas that are colder and more humid. Gleysols and histosols are frequently found on the valley floors.

The area is rather easily accessible through a dense network of paved and unpaved public forest paths, which are often the legacy of the long-term presence of the army in these border regions under the communist regime.

The climate in this part of Šmava is generally rough (Tolasz et al. 2007), as indicated by the potential vegetation in three of the altitudinal zones of the forest. The lowest altitude zone of the test area, with average annual temperatures of $4.5-5.5^{\circ} \mathrm{C}$ and rainfall of 900 $1,050 \mathrm{~mm}$ per year at an altitude of 800-970 m, falls within the 6th spruce-beech zone. The middle altitude zone, which is situated at an altitude of 970-1,219 m with temperatures of $4.0-4.5^{\circ} \mathrm{C}$ and rainfall of 1,050-1,200 mm per year, is represented by the 7 th beech-spruce vegetation zone. The highest points of the test area, with annual temperatures ranging from 2.5 to $4.0^{\circ} \mathrm{C}$ and annual rainfall of $1,200-1,500 \mathrm{~mm}$, fall within the 8 th zone.

The forest stands have recently undergone considerable changes due to a preference for spruce by the forestry industry. Firs (Abies spp.) and broadleaved trees are very rare. In addition, devastating winds that cause damage to forest stands are now occurring with a continuously decreasing periodicity. Winds with an impact velocity of around $110 \mathrm{~km} / \mathrm{h}$ occur in the Šumava Mountains as many as five times a year. Windstorm Kyrill reached an impact velocity of $170 \mathrm{~km} / \mathrm{h}$, though its average velocity was $130 \mathrm{~km} / \mathrm{h}$ over most of the storm (gusts of $216 \mathrm{~km} / \mathrm{h}$ were recorded on top of Sněžka Mountain). This was the fifth windstorm in the last 25 years. Winds of greater devastating power have a periodicity of about 30 years. The wind, therefore, has become an important phenomenon affecting both the landscape and economy of the Šmava Mountains.

\section{Background to the research hypotheses and aims}

Natural phenomena with enormous devastating power are usually termed natural catastrophes (Bryant 1991) or natural disasters (Alekseyev 1988). The duration will differ depending on the cause of the phenomenon, ranging from several minutes (e.g. avalanches) to hours (e.g. mud torrents), days (landslides) or even several months (floods). Regardless 
of their nature and their progress, when these catastrophes occur (in both space and time) they are subject to the following patterns:

- Each type of catastrophe is typical of a certain specific area and position, i.e. it develops in accordance with the presence and degree of particular natural, and in some cases also anthropogenic, factors.

- Each type of catastrophe will be repeated with a degree of periodicity, i.e. a catastrophe can be expected in locations liable to a certain kind of phenomenon. The actual time of occurrence, however, is bound to a certain number of conditions that must be met.

- The occurrence of each catastrophe can be predicted with a greater or lesser likelihood in relation to its dependence on the scale, duration and intensity of various geological or hydrometeorological processes. It is the high degree of unreliability in the forecasting of these particular processes that causes the greatest problems.

The following risk areas have been identified as regard factors that can initiate the outbreak of a disaster (Mazur and Ivanov 2004):

- Geological-morphological - especially in those areas of the lithosphere with a high relief (e.g. landslides, avalanches, erosion, sinking of land, earthquakes and volcanic eruptions);

- Meteorological-climatic-hydrological - initiated by local atmospheric and hydrological parameters, over the short or long term (e.g. floods, tornados, droughts and wind damage);

- Biotic - caused by "self-development" of a plant or animal species, population, chain or ecosystem, and often induced through biotic catalysers (e.g. changes in moisture or energy balance, insect invasions and outbreaks, changes in biodiversity or invasions of alien species).

Despite the impulse's usually being provided by one of the aforementioned components and the catalyser's usually being a specific characteristic landscape feature or a process taking place within it, the disaster is often complex in its character and has consequences for all segments of the landscape. In fact, other elements take part in the genesis of the catastrophe, even if to a much smaller extent, with some of the elements promoting the disaster and others tending to prevent it. A diminished resistance of an element to the natural disaster can then become a catalyser, or at least an accelerator.

Forest windthrow events are a part of the existence of the forest and the forest economy. Numerous studies have been devoted to spatial (geographic) and objective (forestry) analysis of this phenomenon, and these have lead to improvements in forest stands security and forest management efficiency. As regards forestry management, great attention has been paid to windthrow, whilst historical events and the behaviour of individual trees and canopy types (e.g. ecotones, species composition, age and internal stand sections) have also been carefully studied (imperial decrees of the 19th century prevented forest managers from undertaking clear-cutting and recommended that wide canopy belts be left between clear cuts). Since the beginning of the 20th century, research has focused on the behaviour of the wind within forest stands (e.g. Vicena 2003), and especially on such factors as the participation of the stand and individual trees in the origin of windthrow, the role of landscape features in windthrow occurrence, and the study of wind impact. The following points were identified from a range of studies (e.g. Bielecka 1986; Bielecka et al. 1995; Ruel et al. 2001; Vicena 2003; Mitchell and Lanquaye-Opoku 2004; Gardiner et al. 2008):

- As regards stands and trees, more at risk from windthrow are stands comprising more than $60 \%$ Norway spruce, old and dense stands (thin trunk, elevated centre of gravity 
and high crown), stands affected by disease, stands close to areas of clear-cutting, and trees higher than $33 \mathrm{~m}$ (trees below $22 \mathrm{~m}$ are safe).

- As regards landscape features, the risk of windthrow increases at humid sites, sites on weak rocks, sites located on ridges and with increasing elevation above sea level.

- As regards wind impact, irregular winds with frequent changes in velocity and/or direction over short distances are accepted as the most dangerous for forest stands.

While past results have tended to be either deduced and/or statistically derived from cartographic data, more recent research has been based on GIS technology and spatial statistics. Such studies, however, have been hampered by a lack of detailed geographic information and an absence of documentation regarding windthrow damage. Despite every windthrow event's being unique, and wide variation between the results of each analysis, it is known that windthrow events tend to occur repeatedly, albeit at irregular intervals, in exposed areas. Certain areas with particular natural and forestry features, therefore, appear to be more susceptible to windthrow than others.

In recent years, a number of powerful modelling tools and procedures have been produced with the development of various computer applications (e.g. at the University of Joensuu in Finland, the University of British Columbia in Canada, the Universite Laval in Canada, the University of Tokyo in Japan, and by the Help Forest, Ltd. Company and the Institute of Atmospheric Physics of the Czech Academy of Sciences in the Czech Republic). These tools have helped develop systems of territory classification as regards windthrow risk, and they have been used to model wind behaviour and identify critical wind speeds and wind sensitive areas. These models are based both on empirical experience (measured feature values) and on mechanical computing using physical features of individual trees, forest stands and damaging winds. Consequently, so-called combined, or hybrid, models have been constructed that unify the advantages of both approaches. The most widely known models are the HWIND (University of Joensuu) and GALES (Forestry Commission, Scotland) models, and the ForestGALES_BC model (University of Vancouver) that is still under development. These models have all been tested on stands of Norway spruce, Scots pine (Pinus silvestris), and various American, New Zealand, Japanese and Mediterranean coniferous tree species. All of these models are based on three data classes: 1) canopy features, 2) wind field data, and 3) site/area features (soils, geology, terrain and land use, including forest management style). While the reliability of these models is being continuously tested, they are already being used as the standard method for windthrow risk assessment in some countries (e.g. in Great Britain, France and Denmark).

The Czech company Help Forest Ltd. and the Institute of Forest Management in Brandýs nad Labem (Czech Republic) have both been involved in developing and testing the WINDAREC model. In addition, the Institute of Atmospheric Physics of the Czech Academy of Sciences contributed by applying various wind models and developing new models for wind field modelling (Hošek et al. 2004). The Šumava Mountains are commonly used as the main test area for these models due to the frequency of windthrow events. For this same reason, this territory was selected in 2005 for the geographical analysis of windthrow area distribution and for the application of the results into forest management practice.

Based on the results of field research and available geodata, as well as a search of international literature and on the authors' local knowledge, various research hypotheses were put forward for studying the causes of windthrow in the Šumava National Park following windstorm Kyrill (see Table 1). 
Table 1: List of research hypotheses and an overview of their verification.

\begin{tabular}{cccc}
\hline No. & Variable & Individual hypothesis & Result of research \\
\hline 1 & Slope gradient & Flat areas are more susceptible to windthrow. & Not proven \\
\hline 2 & Aspect & $\begin{array}{c}\text { Windward and leeward slopes are more susceptible to the } \\
\text { general direction of the wind. }\end{array}$ & Partly proven \\
\hline 3 & Elevation & Higher altitudes are more susceptible. & Partly proven \\
\hline 4 & Terrain curvature & Convex surfaces are more susceptible. & Partly proven \\
\hline 5 & $\begin{array}{c}\text { Distance from } \\
\text { the water divide }\end{array}$ & Areas near a water divide are more susceptible. & Not proven \\
\hline 6 & Site humidity & Humid areas are more susceptible. & Partly proven \\
\hline 7 & Soil depth & Shallow soils are more susceptible. & Partly proven \\
\hline 8 & Species composition & Pure stands are more susceptible. & Proven \\
\hline 9 & Age & Old growth is more susceptible. & Proven \\
\hline 10 & Density & Dense growth is more susceptible. & Proven \\
\hline 11 & $\begin{array}{c}\text { Degree of natural } \\
\text { growth }\end{array}$ & Artificial stands are more susceptible. & Proven \\
\hline 12 & Local wind direction & $\begin{array}{c}\text { Areas are more susceptible to windthrow where local wind } \\
\text { direction coincides with overall wind direction. }\end{array}$ & Partly proven \\
\hline 13 & Wind speed & Higher wind speed results in more damage. & \\
\hline
\end{tabular}


GIT offers a variety of tools for spatial analysis. Vast data files have been compiled as a result of the recent damage caused by windstorm Kyrill, and it is our belief that, through spatial analysis of this data, it will be possible to establish the chain of events that led to the damage, and perhaps eventually to identify the periodicity of such phenomena. Such spatial analysis relies on the assumption that the occurrence of windthrow, the amount of damage done and the cost of alleviating such damage are dependent on natural features in the area and previous forestry intervention in the landscape.

The aim of this project, therefore, is to analyse patterns of spatial differentiation in windthrow events in the Šmava National Park caused by windstorm Kyrill and to produce proposals for concrete measures that will alleviate the effects of such windstorms in the future.

\section{METHODS}

As noted above, previous research has identified a number of factors that influence the stability of forests and influence their resistance to strong winds. Based upon an assessment of preliminary data and upon field research in the affected area, a number of decisive factors were chosen to be integrated into this project. These were the key factors of direction and strength of the wind, as well as the configuration of the terrain, including slope gradient, exposure and curvature, and the forest site conditions, including soil depth and moisture regime. In addition to the aforementioned natural factors, other factors that have an impact on the stability of forest stands were also included, i.e. the species, age and spatial composition of the forest stands.

Geodata for the territorial analysis of the test area was supplied by the Šumava National Park administration as part of an agreement on joint action in implementation of the STRiM project.

Shortly after the wind disaster, the Šumava National Park administration mapped the affected areas using accurate GPS measurements and a primary evaluation of the damage was undertaken in which three categories of damage were established. The respective areas were then documented in geodatabases. A digital model of the terrain was constructed using the level line scheme of the DMÚ 25 data set (a digital territorial model constructed by the Czech army using topographic maps at a scale of 1:25,000). Maps of the exposure, slope gradient and relief curvature of the terrain were subsequently produced based on this data. Data for the natural conditions within the affected areas of the Šumava forest were taken from documentation of the Regional Forest Development Plans, produced by the Institute of Forest Management at Brandýs nad Labem (and from the digital typological map in particular). This data was used to produce maps of soil and moisture conditions. Meteorological data for wind direction and strength at the time of windstorm Kyrill were obtained from the Czech Hydrometeorological Institute station at Churáňov $(1,118 \mathrm{~m})$ and from the German Weather Service station at Grosser Arber (1,456 m) (acquired through personal communication with the national park administration).

When analysing the data, the wind disaster areas were first united into a single category and compared with differentiation in the territory with regard to the natural factors. The relationships between windthrow occurrence and the relevant natural and forestry factors were then evaluated based on the digital terrain model and data attached to the digital forestry typological map. Input parameters for the analysis were chosen based upon the data input and data on factors that influence the stability of stands, such as the natural character of the stand, age, stand density, trunk diameter coefficient, humidity and the depth of soil. 
Terrain parameters, such as slope gradient, exposure and curvature, were also taken into account. In addition, as a great number of the windthrow occurrences were in the proximity of the watershed, data on distance from the watershed was also gathered during field research and included into the data set. Given the extent of the area, it proved both impractical and time-consuming to create a map of "forest naturalness" based on a direct comparison of current species composition from the stand map and the natural species composition based on the forestry typological map. For this reason, the current species composition for all stand groups in the area was converted, using a preset macro in Microsoft Excel ${ }^{\odot}$, into a stand "type" (based on the methodology of Vyskot et al. 2003). A comparison of this stand type with the natural stand type produced a value for "naturalness" ranging on a scale of one to six (where $1=$ non-natural forest and $6=$ natural forest). Considering the altitude of the area (vegetation zone 6-8), the presence of spruce is considered natural and, therefore, the naturalness of the stands ranged between values of 3 and 6. A map was produced for each factor, and this factor map was then compared with the map of territorial windthrow distribution. The proportion (in \%) of total windthrow area within each of the areas covered by the various natural and forestry variables could then be calculated.

For the second stage of analysis, a two-stage process was used:

1) Each natural landscape feature was evaluated by a group of experts as regards its potential impact on the stability of the surrounding trees and given a qualitative score ranging from zero to three (with three representing the greatest impact). The feature maps were then reclassified as a set of risk maps, each representing four classes of susceptibility to windthrow.

2) Secondly, the relative importance of landscape features was assessed (weighted) in a similar manner, using the same scale of zero to three, and presented as a histogram of frequency of occurrence in each of the areas covered by the various natural and forestry variables. Factor categories with low histogram values were considered as less important as regards risk of windfall.

An integrated risk assessment map was produced by first subjecting the weighted maps of individual factors to map algebra using the method of Orgando et al. (2005). The resulting values were divided into five categories (where five represents greatest risk) based upon their estimated susceptibility to wind damage. The relationship between the risk rate of a spot area and the occurrence of windthrow during windstorm Kyrill was then compared on the resulting map.

\section{RESULTS AND DISCUSSION}

Comparison of the various parameters with those areas damaged by wind indicates varying degrees of relationship. The results of windthrow territorial distribution analysis when all site features are combined already show a relationship, albeit limited, to both natural and biotic stand features. From this analysis, wind behaviour appears to be the factor with the most important role in damage generation. The further study of wind behaviour, however, remains outside the scope of this study. 
Spatial analysis of the data used in this study indicates varying relationships between the occurrence of wind damage and a number of individual natural factors (see Table 1). Terrain features tend to have only a partial impact on the area of windthrow distribution. Our studies indicate, however, that a) the most damaged stands were generally found on gently sloping sites of $8-15$ degrees; b) the leeward side of elevations (with respect to general, not local wind direction) were heavily damaged, while windward areas were slightly less damaged; c) non-natural forest stands were subject to more damage; d) damage increased with increasing stand density (Figure 2); e) middle-aged stands were at greatest risk (Figure 3); and f) the most damaged areas in the test area were located at sites with normally drained and deep soils, while forest stands on shallow soils, where trees were strongly rooted in rock fissures and around boulders, were less damaged.

Spatial analysis of the relationships between the integrated risk classes and actual windthrow areas shows a high degree of concurrence, i.e. those areas identified as most at risk were those where the overwhelming majority of recorded windthrow occurred (Figure 4). Fifty percent of windthrow surface area was in the very high danger zone and nearly $40 \%$ in the high danger zone (Figure 4). Despite this, the methods used cannot be considered as producing conclusive results. The results indicate that the action of the wind is clearly influenced by landscape features and other factors (e.g. surface roughness), though these factors do not affect the main impact of the wind. Any actual reduction in the impact of wind velocity is likely to be linked to the high spatial and temporal variability of wind behaviour at the time of maximum attack, a feature that cannot be reflected in the wind field model at the Institute of Atmospheric Physics of the Czech Academy of Sciences. It should be noted, however, that, as yet, only some of the accessible methods of data processing have been used.

The accuracy of the data entered into the model is also likely to have affected the accuracy of the analysis. As regards the landscape features (taken from DMÚ 25), it is vitally important that the data is discriminated accurately. As far as the forestry data are concerned, there may be doubts concerning the accurate positioning of places or the description of site conditions. Due to the size of the area studied, however, it was not possible to undertake a detailed and accurate mapping of the site conditions. As suitable data processing technology becomes more widely available, studies of the aerodynamic factors involved will be of great use.

Further research is needed into factors affecting local wind action and future studies should pay greater attention to the history of forest stands - both those affected and those neighbouring them. There is no doubt that the landscape, its configuration and the character of the surface play decisive roles in modifying both the wind's direction and speed, and thus in its devastating power. At individual locations, however, wind direction may not correspond with data from meteorological stations as the landscape pattern, the surface and its surroundings will all have an influence. Winds with ground-level speeds such as that displayed during a windstorm are also subject to eddying and frequent fluctuations in direction, height and speed over short periods of time. This does not mean, however, that spatial analysis has no relevance in such studies. 
Fig. 2: Forest stands density in the Šumava National Park test area.
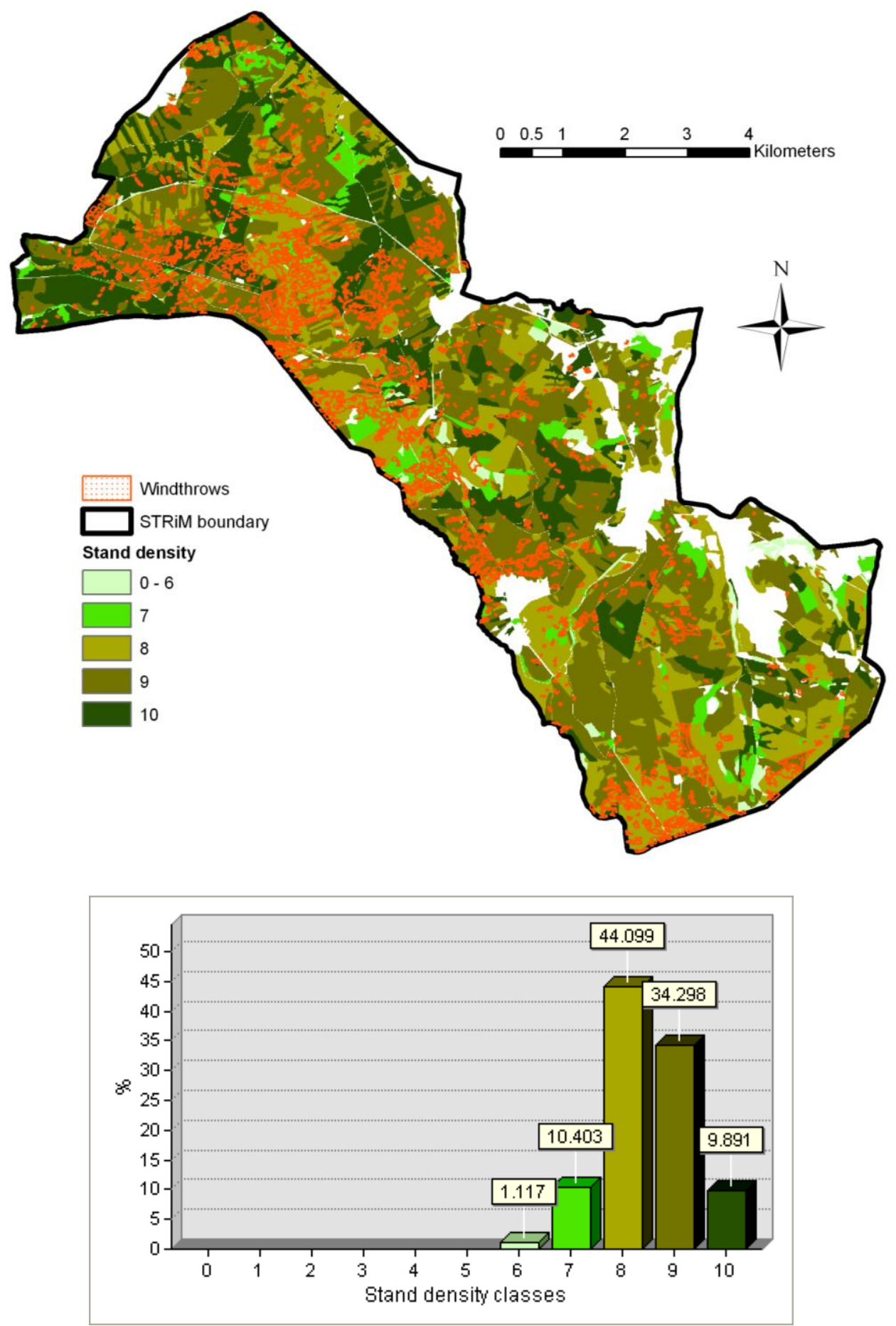
Fig. 3: Forest stands age (10- year's classes) in the Šumava National Park test area.
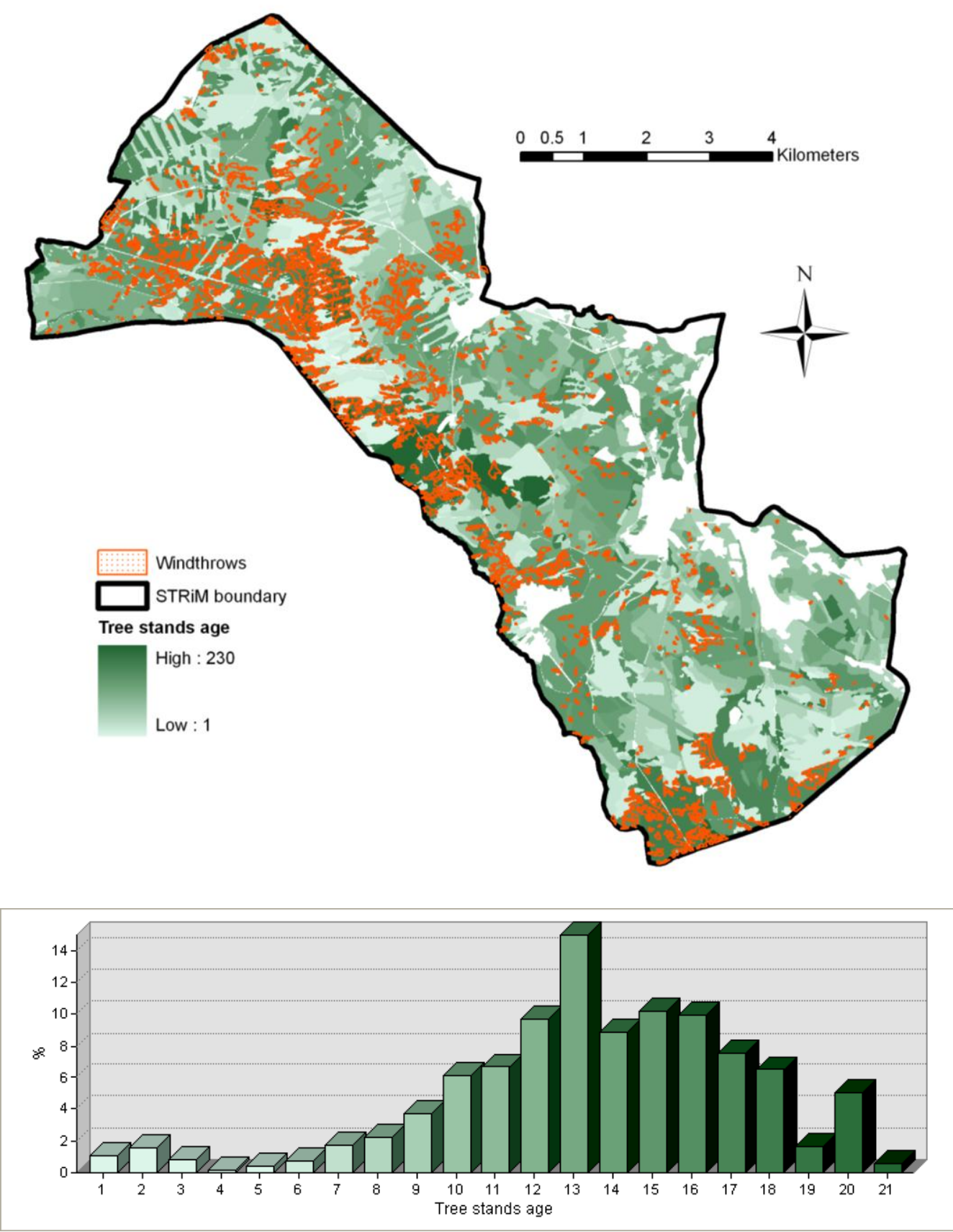
Fig. 4: Weighted risk analysis classes in the Šumava National Park test area
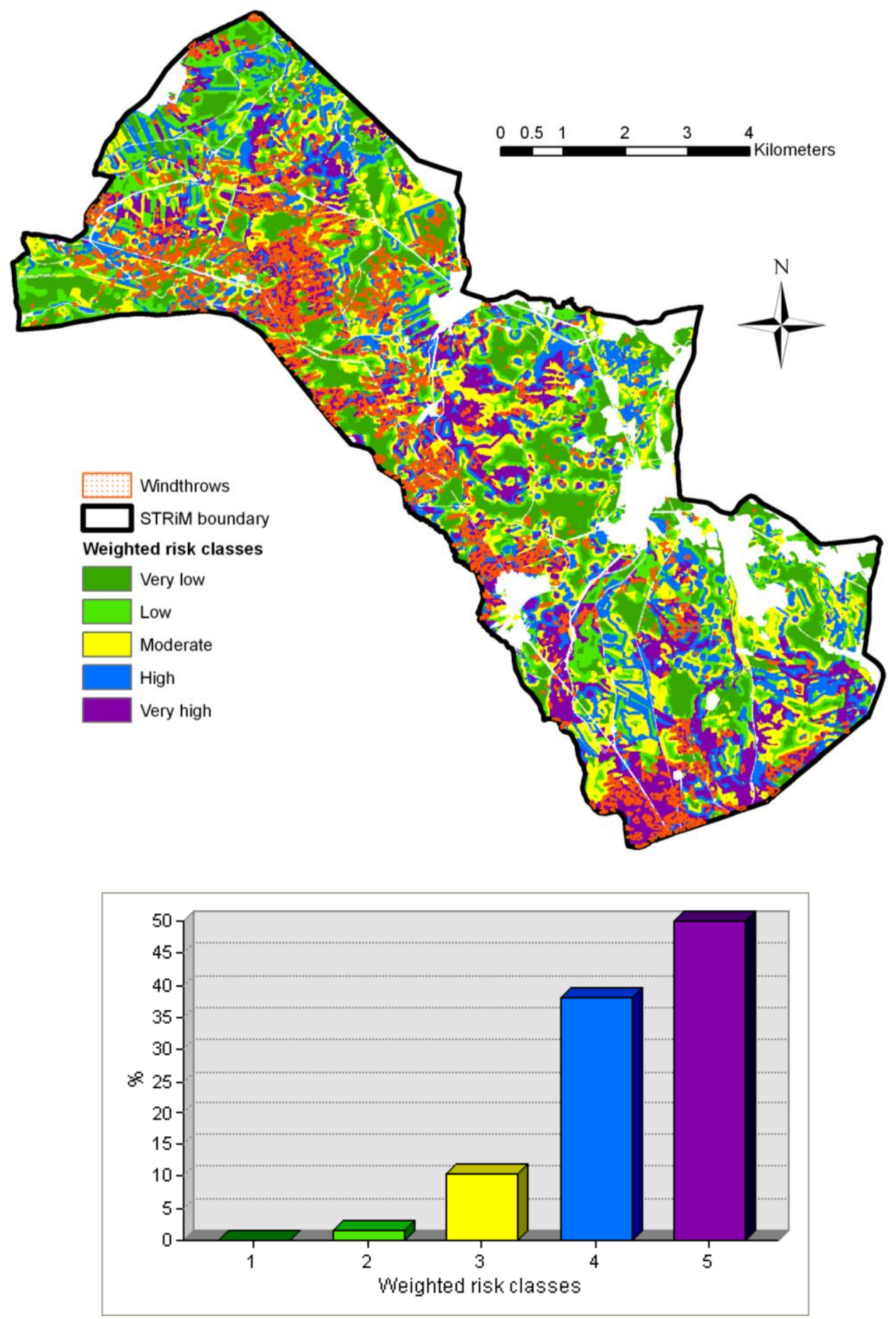


\section{CONCLUSION}

The results of territorial analysis of windthrow caused by windstorm Kyrill indicate that there is a connection between the occurrence of windthrow and features within the natural environment. The results of this study will both support and improve forest management measures, thereby increasing the resistance of the forest to wind damage in the future. The windthrow risk map generated can be used for regional planning, disaster management and in support of future forestry management measures. With growing evidence for increases in wind damage in forests and its connection with global climate change, it has become both an ecological and economic necessity to intensify the study of this phenomenon.

\section{ACKNOWLEDGEMENTS}

The analysis and research into wind damage in forest stands in the Šumava Mountains was undertaken as part of the STRiM project (project number 5D008), which is supported by the European Union's INTERREG IIIB CADSES programme.

\section{REFERENCES}

Alekseyev, N.A. (1988). Stikhiynyye yavleniya $v$ prirode: proyavleniye, effektivnost zashchity. Mysl, Moscow, pp 254.

Bielecka, E., Fedorowicz - Jackowski, W. \& Witkowska, E. (1995). Sequential monitoring of Tatra subalpine forests on the basis of cartographic and remotely-sensed data. In: Breymeyer, A. (Ed.): EURO-MAB IV - Mountain zonality facing global change, pp 119130. Zakopane 1993, Conference papers 21, Institute of Geography and Spatial Organization, Polish Academy of Science, Warsaw,

Bielecka, E. (1986). Photointerpretation survey of changes in the range of the Tatra subalpine forests. Miscelanea Geographica, 125-131.

Brázdil, R. (2004). History of weather and climate in Czech lands VI: Strong winds. Masaryk University, Brno, pp 378.

Brázdil, R. (2007). Vybrané prírodní extrémy a jejich dopady na Moravě a ve Slezsku. Brno/Praha/Ostrava, MU/ČHMÚ/ÚGN AV ČR.

Bryant, E.A. (1991). Natural Hazards. Cambridge University Press, Cambridge.

Gardiner, B. (2008). A review of mechanistic modelling of wind damage risk to forests. Forestry, 81 (3): 447-463.

Hošek, J., Jež, J., Svoboda, J. \& Štekl, J. (2004). Comparison of the Mean Wind Speed Fields Computed by Three Models over the Area of the Czech Republic. DEWI (Wind Energy), 13 (24): 66-71.

Jelínek, J. (1985). Větrná a kưrovcová kalamita na Šumavě z let 1868 až 1878. Ústav pro hospodářskou úpravu lesů, Brandýs n. L.

Mazur, I.I., Ivanov, O.P. (2004). Opasnyye prirodnyye processy. Ekonomika, Moscow.

Mitchell, S., Lanquaye-Opoku, N. (2004). Windthrow Hazard Mapping using GIS. Canadian Forest Products TFL 30. McGregor Model Forest. Final Report. University of British Columbia, Vancouver. 
Orgando, G., Selicato, F. \& Torre, C.M. (2005). The Use of GIS as a Tool to Support Risk Assessment. In: Van Oosterom, P., Zlatanova, S. \& Fendel, E.M. (Eds): Geo-Information for Disaster Management. pp 1381-1399. Springer, Berlin-Heidelberg,

Pelc, Z. (1994). Geologická mapa ČR. List 22-33 Kašperské Hory. M 1:50 000. Czech Geological Survey, Prague.

Ruel, J.C., Pin, D. \& Cooper, K. (2001). Windthrow in riparian buffer strips: effect of wind exposure, thinning and strip width. Forest Ecology and Management, 143 (1-3): 105-113.

Ševětínský, J. (1895). Dějiny lesů v Čechách. Písek. pp 238

Tolasz, (2007). Climate Atlas of Czechia. Praha, Olomouc, ČHMÚ, UPOL.

Vejnar, Z. (1991). Geologická mapa ČR. List 21-44 Železná Ruda. M 1:50 000. Czech Geological Survey, Prague.

Vicena, I. (2003). Námraza v našich lesích. Písek, Matice lesnická.

Vyskot, I. (2003). Kvantifikace a hodnoceni funkci lesü České republiky. Praha, MŽP ČR.

Watson, R.T., Zinyowera, M.C., Moss, R.H. \& Dokken, D.J. (1995). Climate Change 1995: Impacts, Adaptations and Mitigation of Climate Change. Scientific-Technical Analyses. Cambridge University Press, Cambridge. 